\title{
Efficacy of Topical Terbinafine and Topical Clotrimazolein the treatment of Dermatophytosis and Skin Candidiasis; an Observational Study
}

\author{
Farah $\mathrm{S}^{1}$, Sadaf $\mathrm{J}^{2}$, Muhammad $\mathrm{A}^{3}$ and Muhammad $\mathrm{FF}^{4 *}$ \\ ${ }^{1}$ Department of Medicine, Al-Tibri Medical College and Hospital \& Isra University Karachi, Pakistan \\ ${ }^{2}$ Department of General Surgery, Al-Tibri Medical College and Hospital, Pakistan \\ ${ }^{3}$ MCSW, Research Officer at R\&D department, Al-Tibri Medical College and Hospital, Pakistan \\ ${ }^{4}$ Statistician at R\&D department, Al-Tibri Medical College and Hospital, Pakistan \\ Submission: September 18, 2017; Published: January 19, 2018
}

*Corresponding author: Muhammad Faisal Fahim, Statistician, Research \& Development, Al-Tibri Medical College and Hospital, Isra University Karachi, Pakistan; Email: faisalfahim88@hotmail.com

\begin{abstract}
Objective: To compare the efficacy of Topical Clotrimazole and Topical Terbinafine in topical Fungal infection clinically.

Study Design: It is a Cross sectional observational study.

Place and Duration of study: The study was conducted in Altibri Medical College and Hospital, from December 2016 to June 2017.

Materials and Methods: The study was carried out in 105 patients of all age groups. Diagnosis was done on clinical grounds. Informed consent was taken from all the patients. All the patients were followed for 6-7 weeks and were observed for clinical improvement of sign and symptoms. Statistical analysis of the data which includes the numbers and percentages was done for all the categories via SPSS ver 22.

Results: Among 46 patients of Tinea Corporis, 21 were given Topical Terbinafine and 19(90.4\%) improved in 2 weeks. 25 patients were given Topical Clotrimazole and 22(88\%) improved in 2 weeks. Among 23 patients of Tinea Cruris 13 patients were given Topical Terbinafine, $11(84.4 \%)$ treated in 2 weeks. 10 patients were given Clotrimazole Topical, $8(80 \%)$ patients treated in 2 weeks. Among 11 patients of Vaginal Candidiasis, 6 patients were given topical Clotrimazole, 3(50\%) treated completely in 2 weeks, 5 were given Topical Terbinafine, 4(80\%) treated in 2 weeks. This shows that Topical Terbinafine is slightly more effective than Topical Clotrimazole. Among 25 patients of TineaPedis, 11 were given Topical Terbinafine, $7(63.6 \%)$ improved in 2 weeks, 14 were given Topical Clotrimazole but no one improved in 2 weeks, $9(64 \%)$ responded in 6 weeks, $3(21 \%)$ in 4 weeks, $1(7 \%)$ in 5 weeks and 1(7\%) didn't responded well in 6 weeks and treatment was extended for 7 weeks. This shows that Topical terbinafine is more effective than Topical Clotrimazole in the treatment of TineaPedis.
\end{abstract}

Conclusion: Topical Terbinafine and Topical Clotrimazole are of almost equall in their efficacy for the treatment of TineaCorporis, TineaCruris and Vaginal Candidiasis with Topical Terbinafine is slightly more effective than Clotrimazole. In Tinea Pedis Topical Terbinafine is more effective than Topical Clotrimazole in terms of shorter duration of treatment requiring only 2-3 weeks of treatment while Clotrimazole takes 4-6weeks for treatment.

Keywords : Clotrimazole; Terbinafine; Dermatophytosis; Candidiasis

\section{Introduction}

Fungal skin infection also called ringworm is a red, circular itchy rash. It is known as Tinea or Dermatophytosis [1]. It is referred by other names according to the part of the body affected. For example, Tinea on head is called Tinea Capitus, it is called TineaCruris if it involves the groin, it is called Tinea Pedis if it involves the feet, fungal infection of nails is Tenia Unguim or Onychomycosis and fungal infection of the body is Tinea Corporis [2-4]. Fungi reproduce by spreading microscopic spores. These spores are often present in air and soil. They can be inhaled or they come in contact with surface of the skin.
Consequently fungal infection begin in lungs or skin [4]. Fungus candida is naturally occurring microorganism in the vaginal area. Lactobacillus keeps its growth in check. If there is an imbalance in defence system it grows and causes Candidiasis [5]. These infections are treated with topical antifungals [6]. In this study topical Terbinafine and topical Clotrimazole is compared with each other in their efficacy to treat Dermatophytosis [6-8].

Terbinafine is an allylamine derivative that has fungicidal properties [9]. It is by development of high intracellular squalene concentrations, which are believed to interfere 
with fungal membrane function and cell wall synthesis. In case of candida albicans, growth inhibition with terbinafine appears to result from ergosterol deficiency. Clotrimazole is an Imidazole derivative with a broad spectrum of antimycotic activity [10]. It alters the permeability of the fungal cell wall. It binds the phospholipids of cell membrane and inhibits the biosynthesis of ergosterol and other sterols required for cell membrane production. So it has 'Fungistatic' effect [10]. Topical preparations are used for superficial fungal skin infections and oral preparations are used for deep and systemic fungal infections [6,10].

\section{Materials and Methods}

The study was carried out in 105 patients of all age groups. Patients of all age groups with Dermatophytosis and Skin Candidiasis were selected for this study. Patients of Onychomycosis and Tenia Capitis were excluded from this study because Onychomycosis and Tenis capitis is treated by oral antifungals. Diagnosis was done on clinical grounds. Informed consent was taken from all the patients. A detailed history including age, sex, and occupation, duration of disease and family history of the patients was obtained. A dermatological examination was done, taking care to note the morphology and distribution of the fungal infection. All the cases were diagnosed clinically. All the patients were followed for 6-7 weeks and were observed for clinical improvement of sign and symptoms. Statistical analysis of the data which includes the numbers and percentages was done for all the categories via SPSS ver 22 .

\section{Results}

Among 46 patients of Tinea Corporis, 21 were given Topical Terbinafine and $19(90.4 \%)$ improved in 2 weeks. 25 patients were given Topical Clotrimazole and 22(88\%) improved in 2 weeks. Among 23 patients of TineaCruris 13 patients were given Topical Terbinafine, $11(84.4 \%)$ treated in 2 weeks. 10 patients were given Clotrimazole Topical, $8(80 \%)$ patients treated in 2 weeks. Among 11 patients of Vaginal Candidiasis, 6 patients were given topical Clotrimazole, $3(50 \%)$ treated completely in 2 weeks, 5 were given Topical Terbinafine, 4(80\%) treated in 2 weeks. This shows that Topical Terbinafine is slightly more effective than Topical Clotrimazole. Among 25 patients of TineaPedis, 11 were given Topical Terbinafine, 7(63.6\%) improved in 2 weeks, 14 were given Topical Clotrimazole but no one improved in 2 weeks, $9(64 \%)$ responded in 6 weeks, $3(21 \%)$ in 4 weeks, $1(7 \%)$ in 5 weeks and $1(7 \%)$ didn't responded well in 6 weeks and treatment was extended for 7 weeks. This shows that, Topical terbinafine is more effective than Topical Clotrimazole in the treatment of TineaPedis.

\section{Discussion}

105 patients were selected, with distribution of patients as follows:

46 (43.8\%) had TineaCorporis, 23(21.9\%) had TineaCruris, $25(23.8 \%)$ had TineaPedis and 11(10.5\%) had Vaginal
Candidiasis (Table 1). Among 46 patients of TineaCorporis 21 was given Terbinafine. 19(90.4\%) patients treated completely in 2 weeks [11], 1(4.7\%) responded in 1 week and 1(4.7\%) didn't responded in 2 weeks and the treatment is extended to 3 weeks. 25 patients were given Topical Clotrimazole, 22(88\%) treated in 2 weeks and 3(12\%) didn't responded in 2 weeks and treatment was extended for 3 weeks. Among 23 patients of Tinea Cruris, 13 patients were given Topical Terbinafine, $11(84.4 \%)$ treated in 2 weeks and $2(15.6 \%)$ responded in 1 week [12]. 10 patients were given Clotrimazole Topical, $8(80 \%)$ patients treated in 2 weeks and in $2(20 \%)$ in treatment needed to extend for 3 weeks $[13,14]$. Among 25 patients of TineaPedis, 11 were given Topical Terbinafine, $7(63.6 \%)$ treated in 2 weeks, $2(18.2 \%)$ in 3 weeks and $2(18.2 \%)$ in 4 weeks $[15,16] .14$ patients were given Topical Clotrimazole, $9(64 \%)$ responded in 6 weeks, $3(21 \%)$ in 4 weeks, $1(7 \%)$ in 5 weeks and $1(7 \%)$ didn't responded well in 6 weeks and treatment was extended for 7 weeks $[17,18]$. That shows terbinafine takes less time than Clotrimazole to show clinical improvement in Tinea Pedis [19].

Table 1: Distribution of 105 patients of Dermatophytosis with respect to area involved and given drug.

\begin{tabular}{|c|c|c|c|c|}
\hline & $\begin{array}{c}\text { Tinea } \\
\text { Corporis }\end{array}$ & $\begin{array}{c}\text { Tinea } \\
\text { Cruris }\end{array}$ & $\begin{array}{c}\text { Tinea } \\
\text { Pedis }\end{array}$ & $\begin{array}{c}\text { Vaginal } \\
\text { Candidiasis }\end{array}$ \\
\hline $\begin{array}{c}\text { Patients Treated } \\
\text { with Topical } \\
\text { Clotrimazole }\end{array}$ & 25 & 10 & 14 & 6 \\
\hline $\begin{array}{c}\text { Patients Treated } \\
\text { with Topical } \\
\text { Terbinafine }\end{array}$ & 21 & 13 & 11 & 5 \\
\hline Total No. of Patients & 46 & 23 & 25 & 11 \\
\hline
\end{tabular}

Among 11 patients of Vaginal Candidiasis, 5 were given Topical Terbinafine, $4(80 \%)$ treated in 2 weeks and $1(20 \%)$ treated was needed to extend for 3 weeks. 6 patients were given topical Clotrimazole, $3(50 \%)$ treated completely in 2 weeks and $3(50 \%)$ didn't responded well in 2 weeks and treatment was extended for 3 weeks $[20,21]$. This data clearly indicates that Topical Terbinafine is effective for superficial dermatophytosis and vaginal candidiasis and takes on average 1-2 weeks for clearance of fungal infection [22], with some cases of Tineapedis requiring 2 to 4 weeks as shown in Table 2 [23].

Table 2: Efficacy of Terbinafine with respect to time of treatment.

\begin{tabular}{|c|c|c|c|c|}
\hline Column 1 & $\begin{array}{c}\text { Tinea } \\
\text { corporis }\end{array}$ & $\begin{array}{c}\text { Tinea } \\
\text { cruris }\end{array}$ & $\begin{array}{c}\text { Tinea } \\
\text { Pedis }\end{array}$ & V.Candidiasis \\
\hline 1 week & $4.75 \%$ & $15.60 \%$ & - & $20 \%$ \\
\hline 2 weeks & $90.50 \%$ & $84.40 \%$ & $63.60 \%$ & $80 \%$ \\
\hline 3 weeks & $4.75 \%$ & - & $18.20 \%$ & - \\
\hline 4 weeks & - & - & $18.20 \%$ & - \\
\hline 5 weeks & - & - & - & - \\
\hline 6 weeks & - & - & - & - \\
\hline
\end{tabular}


This table shows that most of the patients responded in 2-3 weeks while patients of TineaPedis took 4-6 weeks. Above data shows that, topical terbinafine is more effective than Topical Clotrimazole [23-25]. The Cochrane Database of systemic review reported 72 placebo controlled trials of topical agents that yielded the following cure rates: undecenoic acid, 72\%; allylamines (terbinafine, naftifine, butenafine), 70\%; tolnaftate, 64\%; azoles (clotrimazole, miconazole, ketoconazole, econazole, oxiconazole), 47\% [26]. A meta-analysis of 11 RCTs suggests that Allylamines are slightly more effective than Azoles. Oral antifungals are expensive and can cause systemic side effects. Ketoconazole and Griseofulvin are approved for oral therapy but product labels clearly state that they should be used only after topical agents have failed (Table 3).

Table 3: Efficacy of Clotrimazole with respect to time of treatment.

\begin{tabular}{|c|c|c|c|c|}
\hline Column 1 & Column 2 & Column 3 & Column 4 & Column 5 \\
\hline Corporis & $\begin{array}{c}\text { Tinea } \\
\text { Cruris }\end{array}$ & $\begin{array}{c}\text { Tinea } \\
\text { Pedis }\end{array}$ & V.Candidiasis \\
\hline 1 week & - & - & - & - \\
\hline 2 weeks & $88 \%$ & $80 \%$ & - & $50 \%$ \\
\hline 3 weeks & $12 \%$ & $20 \%$ & - & $50 \%$ \\
\hline 4 weeks & - & - & $21 \%$ & - \\
\hline 5 weeks & - & - & $7 \%$ & - \\
\hline 6 weeks & - & - & $64 \%$ & - \\
\hline 7 weeks & - & - & $7 \%$ & - \\
\hline
\end{tabular}

\section{Conclusion}

According to this study Topical Terbinafine and Topical Clotrimazole are of almost equal in their efficacy for the treatment of Tinea Corporis, Tinea Cruris and Vaginal Candidiasis, but Topical Terbinafine is slightly more effective than Clotrimazole. In Tinea Pedis Topical Terbinafine is more effective than Topical Clotrimazole in terms of shorter duration of treatment requiring only 2-3 weeks of treatment while Clotrimazole takes 4-6 weeks for treatment.

\section{References}

1. Ilkit M, Durdu M (2015) Tineapedis: The etiology and global epidemiology of a common fungal infection. Crit Rev Microbiol 41(3): 374-388.

2. Phan NQ Blome C, Fritz F, Gerss J, Reich A, et al. (2012) Assessment of pruritus intensity: Prospective study on validity and reliability of the visual analogue scale, numerical rating scale and verbal rating scale in 471 patients with chronic pruritus. Acta Derm Venereol 92(5): 502507

3. Reich A, Heisig M, Phan NQ, Taneda K, Takamori K, et al. (2012) Visual analogue scale: Evaluation of the instrument for the assessment of pruritus. Acta Derm Venereol 92(5): 497-501.

4. Moriarty B, Hay R, Morris JR (2017) The diagnosis and management of tinea. BMJ 345: e4380.

5. Routt ET, Jim SC, Zeichner JA, Kircik LH (2014) What is new in fungal pharmacotherapeutics? J Drugs Dermatol 13(4): 391-395.
6. Tamil SA, Gutha G, Vijaybhaskar, Suthakaran R (2013) Comparative evaluation of newer topical antifungal agents in the treatment of superficial fungal infections (tinea or dermatophytic) Int Res J Pharm $4: 224-228$.

7. Adams BB (2012) Tinea Corporis gladiatorum. J Am Acad Dermatol 47(2): 286-290.

8. Sun PL, Ho HT (2016) Concentric rings: an unusual presentation of tinea corporis caused by Microsporum gypseum. Mycoses 49(2):150151.

9. Vidhya LCP, Bengalorkar GM, Shiva Kumar V (2013) Clinical efficacy of topical terbinafine versus topical luliconazole in treatment of tinea corporis/tinea cruris patients. Br J Pharm Res 3(4): 1001-1014.

10. Schreuder MF, Van de Kar NC, Brüggemann RJ (2016) Drug-Drug Interactions in Treatment Using Azole Antifungal Agents. JAMA 315(23): 2622.

11. Jerajani H, Janaki C, Kumar S, Phiske M (2013) Comparative assessment of the efficacy and safety of sertaconazole $(2 \%)$ cream versus terbinafine cream $(1 \%)$ versus luliconazole $(1 \%)$ cream in patients with dermatophytoses: A pilot study. Indian J Dermatol 58(1): 34-38.

12. Choudhary S, Bisate S, Singh A, Koley S (2013) Efficacy and safety of terbinafine hydrochloride $1 \%$ cream versus sertaconazole nitrate $2 \%$ cream in tineacorporis and tineacruris: A comparative therapeutic trial. Indian J Dermatol 58: 457-460.

13. Goldust M, Rezaee E, Rouhani S (2013) Double blind study of sertaconazole $2 \%$ cream vs. clotrimazole $1 \%$ cream in treatment of seborrheic dermatitis. Ann Parasitol 59: 25-29.

14. Florian S, Mirjana Z, Yvonne G, Peter E, Uta-Christina H (2007) Widespread tineacorporis caused by Trichophytonrubrum with nontypical cultural characteristics-diagnosis via PCR. Mycoses 50(2): 2630.

15. Thaker SJ, Mehta DS, Shah HA, Dave JN, Mundhava SG (2013) A comparative randomized open label study to evaluate efficacy, safety and cost effectiveness between topical $2 \%$ azole and topical $1 \%$ terbinafine in tinea infections of skin. Indian J Dermatol 58: 451-456.

16. Chatterjee D, Ghosh SK, Sen S, Sarkar S, Hazra A, et al. (2016) Efficacy and tolerability of topical azole versus topical terbinafine in localized dermatophytosis: A randomized, observer-blind, parallel group study. Indian J Pharmacol 48(6): 659-664.

17. Barnetson RS, Marley J, Bullen M, Brookman S, Cowen P, et al. (2013) Comparison of one week of oral terbinafine $(250 \mathrm{mg} /$ day) with four weeks of treatment with clotrimazole $1 \%$ cream in inter digital tinea pedis. Br J Dermatol 139(4): 675-678.

18. Evans EG, Dodman B, Williamson DM, Brown GJ, Bowen RG (2013) Comparison of terbinafine and clotrimazole in treating tineapedis.BMJ 307(6905): 645-647.

19. Evans EG (2014) A comparison of terbinafine (Lamisil) 1\% cream given for one week with clotrimazole (Canesten) $1 \%$ cream given for four weeks, in the treatment of tinea pedis. Br J Dermatol 130(43): 1214.

20. López MR (2012) Lamisil vs clotrimazole in the treatment of vulvovaginal candidiasis, Candidosis, a new challenge. Clin Dermatol 28: 178-184.

21. Szigeti G, Sedaghati E, Zarei MA, Naseri A, Kocsubé S, et al. (2012) Species assignment and antifungal susceptibilities of black aspergilli recovered from otomycosis cases in Iran. Mycoses 55(4): 333-338.

22. Shivakumar V, Okade R, Rajkumar V, Sajitha K, Prasad SR (2011) Intermittent pulse-dosed terbinafine in the treatment of tinea corporis and/or tinea cruris. Indian J Dermatol 56(1): 121-122.

23. Leyden J (2012) Pharmacokinetics and pharmacology of terbinafine and itraconazole. J Am Acad Dermatol 38(5): 42-47. 
24. Tsunemi Y (2016) Oral Antifungal Drugs in the Treatment of Dermatomycosis. Med Mycol J 57(2): 71-75.

25. (2014) 1Epidemiologic surveillance of cutaneous fungal infection in the United States. J Am Acad Dermatol 50(5): 748-752.
26. Pires CA, Cruz NF, Lobato AM, Sousa PO, Carneiro FR, et al. (2014) Clinical, epidemiological and therapeutic profile of dermatophytosis. An Bras Dermatol 89(2): 259-264.

\section{Your next submission with Juniper Publishers} will reach you the below assets

- Quality Editorial service

- Swift Peer Review

- Reprints availability

- E-prints Service

- Manuscript Podcast for convenient understanding

- Global attainment for your research

- Manuscript accessibility in different formats ( Pdf, E-pub, Full Text, Audio)

- Unceasing customer service

Track the below URL for one-step submission https://juniperpublishers.com/online-submission.php 